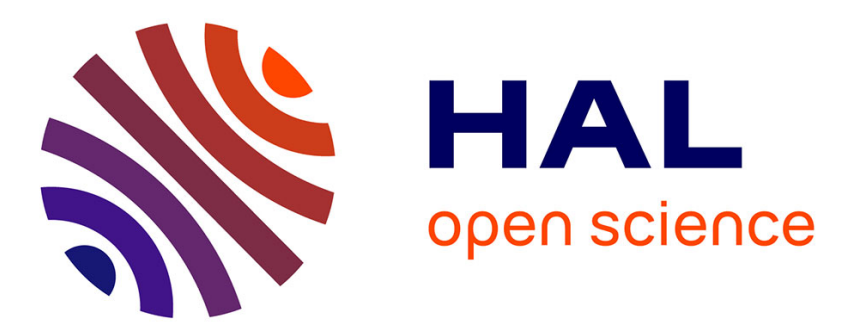

\title{
Mapping upper mantle anisotropy beneath SE France by SKS splitting indicates Neogene asthenospheric flow induced by Apenninic slab roll-back and deflected by the deep Alpine roots.
}

\author{
Guilhem Barruol, Anne Deschamps, Olivier Coutant
}

\section{- To cite this version:}

Guilhem Barruol, Anne Deschamps, Olivier Coutant. Mapping upper mantle anisotropy beneath SE France by SKS splitting indicates Neogene asthenospheric flow induced by Apenninic slab roll-back and deflected by the deep Alpine roots.. Tectonophysics, 2004, 394 (1-2), pp.125-138. 10.1016/j.tecto.2004.08.002 . hal-00109313

\section{HAL Id: hal-00109313 \\ https://hal.science/hal-00109313}

Submitted on 4 Nov 2016

HAL is a multi-disciplinary open access archive for the deposit and dissemination of scientific research documents, whether they are published or not. The documents may come from teaching and research institutions in France or abroad, or from public or private research centers.
L'archive ouverte pluridisciplinaire HAL, est destinée au dépôt et à la diffusion de documents scientifiques de niveau recherche, publiés ou non, émanant des établissements d'enseignement et de recherche français ou étrangers, des laboratoires publics ou privés. 


\title{
Mapping upper mantle anisotropy beneath SE France by SKS splitting indicates Neogene asthenospheric flow induced by Apenninic slab roll-back and deflected by the deep Alpine roots
}

\author{
Guilhem Barruol $^{\mathrm{a}, *}$, Anne Deschamps ${ }^{\mathrm{b}}$, Olivier Coutant ${ }^{\mathrm{c}}$ \\ ${ }^{\mathrm{a}}$ Laboratoire de Tectonophysique, CNRS, Univ. Montpellier II, 34095 Montpellier, France \\ ${ }^{\mathrm{b}}$ Géosciences Azur, CNRS/UNSA, 250, Rue Albert Einstein, F-06560 Valbonne, France \\ ${ }^{\mathrm{c}}$ Laboratoire de Géophysique Interne et Tectonophysique, CNRS, Université Joseph Fourier F38041 Grenoble, France
}

Received 21 November 2003; accepted 2 August 2004

Available online 18 October 2004

\begin{abstract}
The presence of two regional seismic networks in southeastern France provides us high-quality data to investigate upper mantle flow by measuring the splitting of teleseismic shear waves induced by seismic anisotropy. The 10 three-component and broadband stations installed in Corsica, Provence, and western Alps efficiently complete the geographic coverage of anisotropy measurements performed in southern France using temporary experiments deployed on geodynamic targets such as the Pyrenees and the Massif Central. Teleseismic shear waves (mainly SKS and SKKS) are used to determine the splitting parameters: the fast polarization direction and the delay time. Delay times ranging between 1.0 and $1.5 \mathrm{~s}$ have been observed at most sites, but some larger delay times, above $2.0 \mathrm{~s}$, have been observed at some stations, such as in northern Alps or Corsica, suggesting the presence of high strain zones in the upper mantle. The azimuths of the fast split shear waves define a simple and smooth pattern, trending homogeneously WNW-ESE in the Nice area and progressively rotating to NW-SE and to NS for stations located further North in the Alps. This pattern is in continuity with the measurements performed in the southern Massif Central and could be related to a large asthenospheric flow induced by the rotation of the Corsica-Sardinia lithospheric block and the retreat of the Apenninic slab. We show that seismic anisotropy nicely maps the route of the slab from the initial rifting phase along the Gulf of Lion (30-22 Ma) to the drifting of the Corsica-Sardinia lithospheric block accompanied by the creation of new oceanic lithosphere in the Liguro-Provençal basin (22-17 Ma). In the external and internal Alps, the pattern of the azimuth of the fast split waves follows the bend of the alpine arc. We propose that the mantle flow beneath this area could be influenced or perhaps controlled by the Alpine deep penetrative structures and that the Alpine lithospheric roots may have deflected part of the horizontal asthenospheric flow around its southernmost tip.
\end{abstract}

Keywords: Shear wave splitting; Anisotropy; Asthenosphere; Western Mediterranean; Alpine collision; Massif Central hotspot

* Corresponding author. Now at: Laboratoire Terre-Océan, Université de Polynésie française, BP 6570, 98702 Faaa Aéroport, Tahiti, Polynésie française, France. Fax: +689803842 .

E-mail addresses: barruol@upf.pf (G. Barruol), deschamps@geoazur.unice.fr (A. Deschamps), coutant@ujf-grenoble.fr (O. Coutant). 


\section{Introduction}

Seismic anisotropy can be used as a proxy for the upper mantle flow since it results from minerals elastic anisotropy (e.g., Mainprice et al., 2000), primarily olivine, which represents the main upper mantle constituent and which is the most anisotropic upper mantle mineral (Nicolas and Christensen, 1987; Ben Ismail and Mainprice, 1998) and from their preferred orientations induced by tectonic flow (Silver, 1996; Savage, 1999). Upper mantle seismic anisotropy is measured from the Earth's surface by using the splitting of teleseismic shear waves: A polarized shear wave crossing an anisotropic medium is split into two perpendicularly polarized waves that propagate at different velocities. Two anisotropy parameters can be retrieved from three-component seismic records: the difference in arrival time $(\delta t)$ between the two split shear waves, which depends on the thickness and on the intrinsic anisotropy of the medium, and the azimuth $\phi$ of the fast split wave polarization planes, which is related to the orientation of the penetrative anisotropic structure.

Southeastern France is a key area to map upper mantle flow because it represents a geographic transition between different tectonic domains that have suffered different tectonic histories that may have induced different penetrative fabrics in the upper mantle: the still active Alpine collision zone to the north and the western Mediterranean oceanic domains and the related subduction systems to the south. The Alpine collision between the Eurasian and the Apulian plates began $30 \mathrm{Ma}$ ago and evolved as a continental lithospheric subduction. The Eurasian plate is presently subducting eastward down to $300 \mathrm{~km}$ beneath the Adriatic promontory in the western Alps, as imaged by seismic tomography (Lippitsch et al., 2003; Piromallo and Faccenna, 2004). The western Mediterranean subduction system also began about $30 \mathrm{My}$ ago. The oceanic Tethys lithosphere was subducting northwestward beneath the Corsica-Sardinia-Calabria continental lithospheric domains. The eastward roll-back of the Apenninic slab (Séranne, 1999; Faccenna et al., 2001a) induced the rotation of the Corsica-SardiniaCalabria block, the opening of the Ligurian basin 20 My ago (Rollet et al., 2002), together with the AlgeroProvençal and of the Tyrrhenian basins $10 \mathrm{My}$ ago (Gueguen et al., 1998; Faccenna et al., 2001b). The
Apenninic slab is presently visible in tomographic images, lying in the transition zone beneath the Apennines and the Calabrian arc (Lucente et al., 1999; Piromallo and Morelli, 2003).

Together with the vicinity of the Alpine belt and the Ligurian oceanic basin, another important structure that may have influenced the upper mantle flow pattern in southern France is the presence of hot mantle material ascending beneath the Massif Central. Regional seismic tomography of the northern Massif Central (Granet et al., 1995a; Granet et al., 1995b) evidenced a low-velocity anomaly down to $300-\mathrm{km}$ depth, interpreted as a mantle plume that fed the Tertiary and Quaternary volcanism (Maury and Varet, 1980), spreading from the northern Massif Central to the Mediterranean shore. Teleseismic shear wave splitting measurements performed on temporary seismic stations on the southern flank of the Massif Central characterized a homogeneous upper mantle anisotropy pattern (Barruol and Granet, 2002), with a fast axis trending NW-SE in the Massif Central and gradually rotating to WNW-ESE toward the Gulf of Lion. The authors proposed that this seismic anisotropy pattern could have been generated by the effect of the Apenninic slab roll-back, the rotation of the Corsica-Sardinia lithospheric block, the opening of the Algero-Provençal basin. In such a model, the hot and less viscous mantle beneath the northern Massif Central could have been deflected and aspirated toward the south-east by the sinking slab.

Mapping the eastward continuation of the anisotropy pattern observed in the Pyrenees (Barruol and Souriau, 1995; Barruol et al., 1998) and in the southern Massif Central (Barruol and Granet, 2002), characterizing the effects of the Alpine structures and deep lithospheric roots, are therefore the primary aims of this paper. After presenting and analyzing the data and the splitting of teleseismic shear waves recorded at two seismic networks located in south-eastern France, we discuss them in light of the Alpine tectonics and the Cenozoic opening of the western Mediterranean.

\section{Data and Results}

The Très Grande Résolution Sismique (TGRS) network is composed of six stations managed by the 
Geoscience-Azur seismology group from the NiceSophia-Antipolis University and began its operations in 1997. Data can be retrieved by Automatic Data Request Manager (AutoDRM) at autodrm@geoazur. unice.fr. The Réseau d'Observations Sismiques des Alpes (RosAlp) network is managed by the Laboratoire de Géodynamique Interne et Tectonophysique (LGIT) installed in the Grenoble University and is running since 1999. Data are interactively accessible through the web at http://www-lgit.obs.ujf-grenoble. fr/observations/rosalp/rosalp1_4.htm. Table 1 lists the station locations presented Fig. 1. All stations are equipped with broadband sensors and record continuously the seismic activity.

In order to get data of the best possible quality, we selected teleseismic events located at distances in the range $85^{\circ}$ to $120^{\circ}$ and of magnitude generally greater than 6.0 (Background Dataset, Table 2) during the period 1999-2002. The event origins and locations (Background Dataset, Table 2) are taken from the U.S. Geological Survey (USGS) Preliminary Determination of Epicenters, and the phase arrivals were computed using the IASP91 Earth reference model (Kennett, 1995).
We measured the shear wave splitting using the Silver and Chan (1991) method which determines the anisotropy parameters, $\phi$ and $\delta t$, that best minimizes energy on the transverse component of the seismogram for a selected time window. We mainly used the SKS phase, but for some events, we used the whole SKS+SKKS wave train. For each event, we report in Table 3 the split phase on which we performed the measurement, the splitting parameters $(\phi, \delta t)$ with their $1 \sigma$ uncertainty, determined from the $95 \%$ confidence interval, and the backazimuth of the event. We also ascribe a quality factor (good, fair, or poor) to the measurements depending on the signal-to-noise ratio of the initial phase, the rectilinear polarization of the horizontal particle motion after anisotropy correction, and the correlation between the fast and slow split shear waves. We present in Fig. 2 few examples of splitting measurements and some demonstrative evidence of azimuthal dependence of the shear wave splitting parameters observed at STET, SAOF, and SMPL.

The individual shear wave splitting results reported Table 3 are plotted Fig. 3 in polar diagrams. The azimuth of the fast split shear wave together with the

Table 1

Station location and mean splitting parameters calculated with all the results $(\mathrm{g}+\mathrm{f}+\mathrm{p})$ or with the only good measurements $(\mathrm{g})$

\begin{tabular}{|c|c|c|c|c|c|c|c|c|}
\hline Station/network & Latitude $\left({ }^{\circ} \mathrm{N}\right)$ & Longitude $\left({ }^{\circ} \mathrm{E}\right)$ & $\phi\left({ }^{\circ}\right)$ & $\sigma \phi\left(^{\circ}\right)$ & $\delta t(\mathrm{~s})$ & $\sigma \delta t(\mathrm{~s})$ & $\begin{array}{l}\text { Number of } \\
\text { measurements }\end{array}$ & Quality \\
\hline \multirow[t]{2}{*}{ OGSI/Rosalp } & 46.034 & 6.754 & -9 & 5 & 2.25 & 0.10 & 5 & g \\
\hline & & & -3 & 4 & 2.13 & 0.11 & 11 & $\mathrm{~g}+\mathrm{f}+\mathrm{p}$ \\
\hline \multirow[t]{2}{*}{ OGGM/Rosalp } & 45.204 & 6.116 & -31 & 9 & 1.69 & 0.17 & 2 & g \\
\hline & & & -24 & 9 & 1.60 & 0.15 & 3 & $\mathrm{~g}+\mathrm{f}+\mathrm{p}$ \\
\hline \multirow[t]{2}{*}{ OGAG/Rosalp } & 44.788 & 6.541 & -48 & 4 & 1.33 & 0.11 & 4 & $\mathrm{~g}$ \\
\hline & & & -48 & 4 & 1.22 & 0.12 & 6 & $\mathrm{~g}+\mathrm{f}+\mathrm{p}$ \\
\hline \multirow[t]{2}{*}{ OGDI/Rosalp } & 44.110 & 6.217 & 101 & 4 & 1.12 & 0.07 & 6 & $\mathrm{~g}$ \\
\hline & & & 102 & 3 & 1.12 & 0.06 & 8 & $\mathrm{~g}+\mathrm{f}+\mathrm{p}$ \\
\hline \multirow[t]{2}{*}{ STET/TGRS } & 44.259 & 6.929 & -58 & 5 & 1.26 & 0.12 & 11 & g \\
\hline & & & -61 & 4 & 1.30 & 0.10 & 19 & $\mathrm{~g}+\mathrm{f}+\mathrm{p}$ \\
\hline \multirow[t]{2}{*}{ RUSF/TGRS } & 43.943 & 5.319 & 103 & 6 & 1.45 & 0.10 & 7 & $\mathrm{~g}$ \\
\hline & & & 103 & 4 & 1.34 & 0.07 & 18 & $\mathrm{~g}+\mathrm{f}+\mathrm{p}$ \\
\hline \multirow[t]{2}{*}{ SAOF/TGRS } & 43.986 & 7.553 & -86 & 4 & 1.33 & 0.05 & 5 & g \\
\hline & & & -84 & 4 & 1.32 & 0.04 & 9 & $\mathrm{~g}+\mathrm{f}+\mathrm{p}$ \\
\hline \multirow[t]{2}{*}{ CALF/TGRS } & 43.753 & 6.922 & -75 & 2 & 1.21 & 0.07 & 9 & $\mathrm{~g}$ \\
\hline & & & -73 & 2 & 1.25 & 0.06 & 19 & $g+f+p$ \\
\hline \multirow[t]{2}{*}{ ARBF/TGRS } & 43.492 & 5.333 & -81 & 4 & 1.33 & 0.10 & 11 & $\mathrm{~g}$ \\
\hline & & & -81 & 3 & 1.35 & 0.08 & 17 & $\mathrm{~g}+\mathrm{f}+\mathrm{p}$ \\
\hline \multirow[t]{2}{*}{ SMPL/TGRS } & 42.094 & 9.285 & -86 & 2 & 1.47 & 0.08 & 11 & $\mathrm{~g}$ \\
\hline & & & -82 & 3 & 1.51 & 0.08 & 15 & $\mathrm{~g}+\mathrm{f}+\mathrm{p}$ \\
\hline
\end{tabular}

The number and quality of individual splitting measurements from which the average values are calculated is tabulated. 


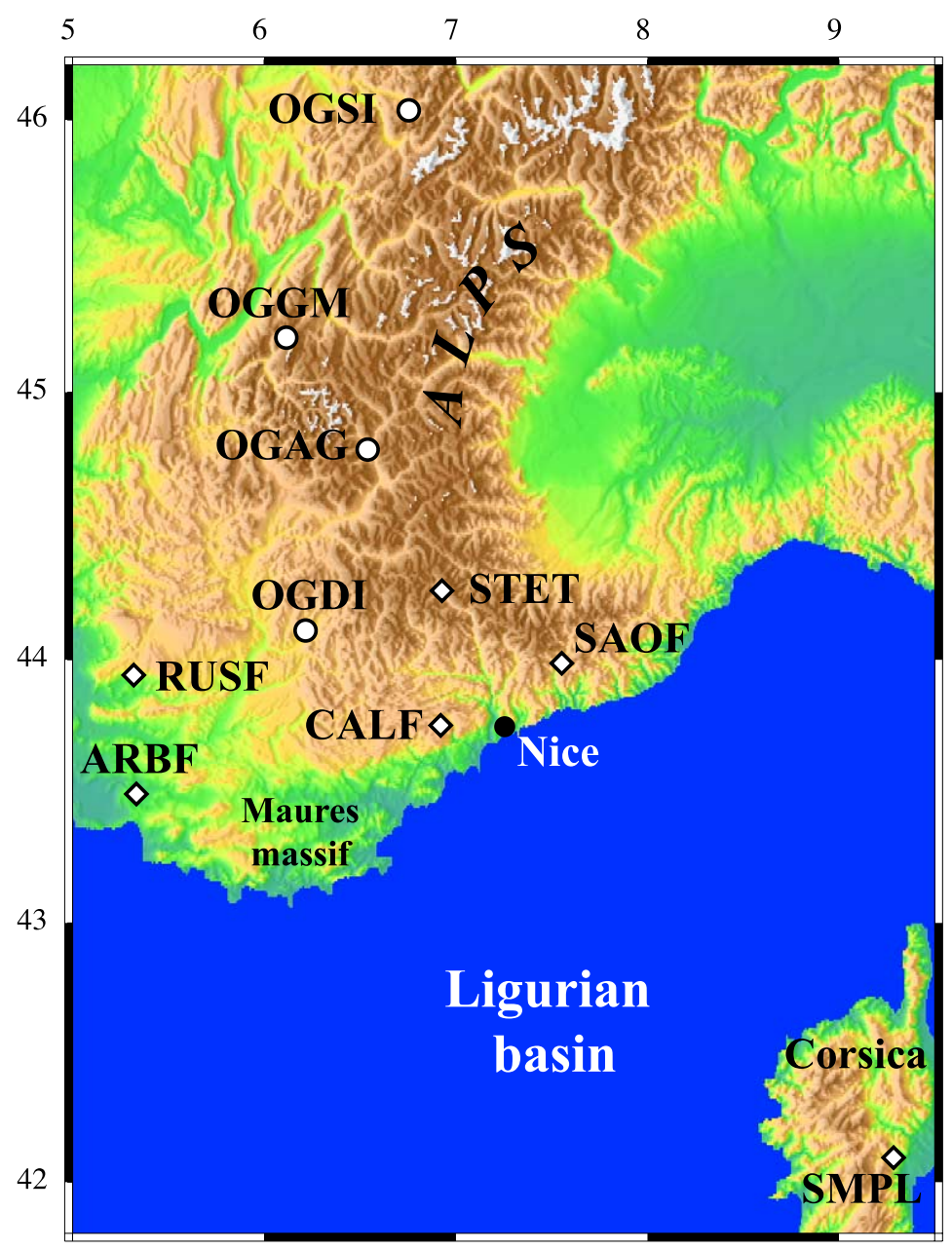

Fig. 1. Map of the station locations. TGRS stations are indicated by diamonds whereas RosAlp stations by circles.

delay time is plotted on the left panel whereas the backazimuth for which no splitting was detected are plotted on the right. Black lines represent the bestconstrained results, whereas the gray lines represent measurements of intermediate quality and dashed lines measurements of poor quality. These diagrams show the coherency and the quality of the results: for most stations, except OGGM where less data were available, results are well constrained by several high-quality splitting measurements. In a first approximation, the high-quality measurements (in black in Fig. 3) show little scattering at most stations, suggesting homoge-

Fig. 2. Examples of splitting measurements at few TGRS and RosAlp stations. For each station, we show two upper traces: the initial radial (a) and transverse (b) components (energy on the transverse component). Two lower traces (c and d): the radial and transverse traces corrected for anisotropy (there is no longer energy on the transverse component). The thick dashed lines display the time window on which the splitting measurement is done and the thin dashed lines represent the predicted phase arrival times (IASP91 model). The four diagrams on the middle panel plot the fast and slow split shear waves (continuous and dashed line, respectively) raw (e) and corrected (f) for the best-calculated delay time. Particle motions in the horizontal plane are shown below, also uncorrected $(\mathrm{g})$ and corrected $(\mathrm{h})$ for the anisotropy: the elliptical particle motion becomes rectilinear when the anisotropy is corrected. The right panel represents the contour plot of energy on the transverse component as a function of the delay time $\delta t(\mathrm{~s})$ and the polarization angle $\phi\left({ }^{\circ}\right)$ of the fast split shear wave. The double contour represents the $95 \%$ confidence interval. 
STET, event 01184 , Backaz N042 ${ }^{\circ}$ E, dist. $103^{\circ}$

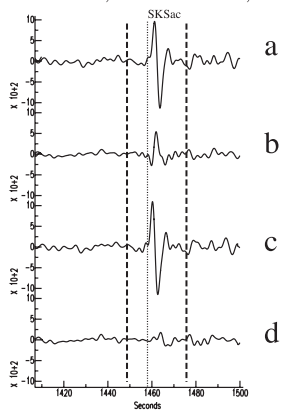

STET, event 00114 , Backaz N236 ${ }^{\circ}$, dist. $96^{\circ}$

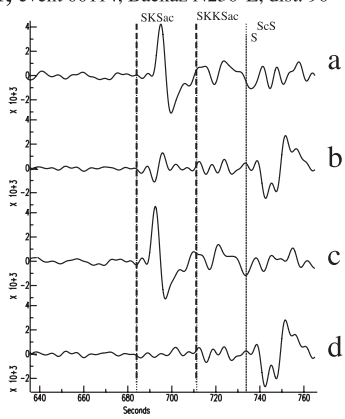

SAOF, event 00219 , Backaz N041 ${ }^{\circ}$ E, dist. $95^{\circ}$

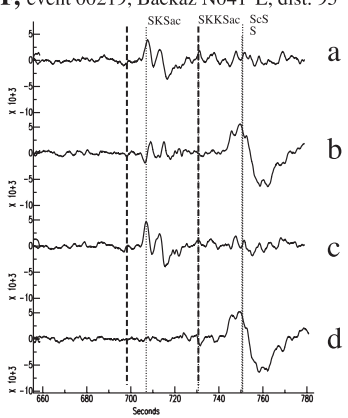

SAOF, event 00133 , Backaz N242 ${ }^{\circ}$, dist. $95^{\circ}$

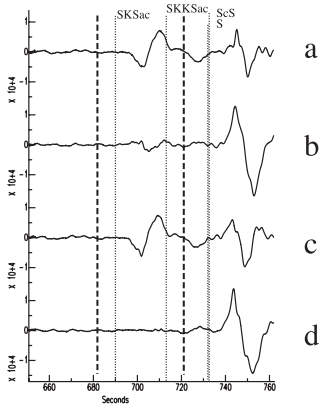

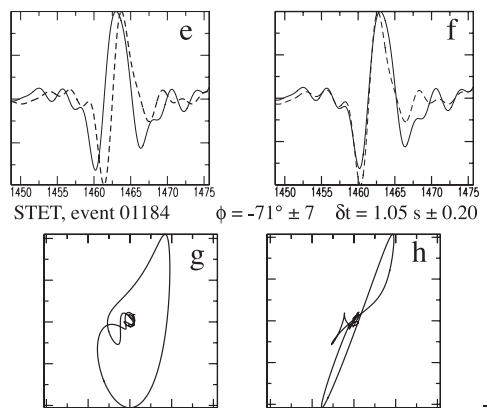
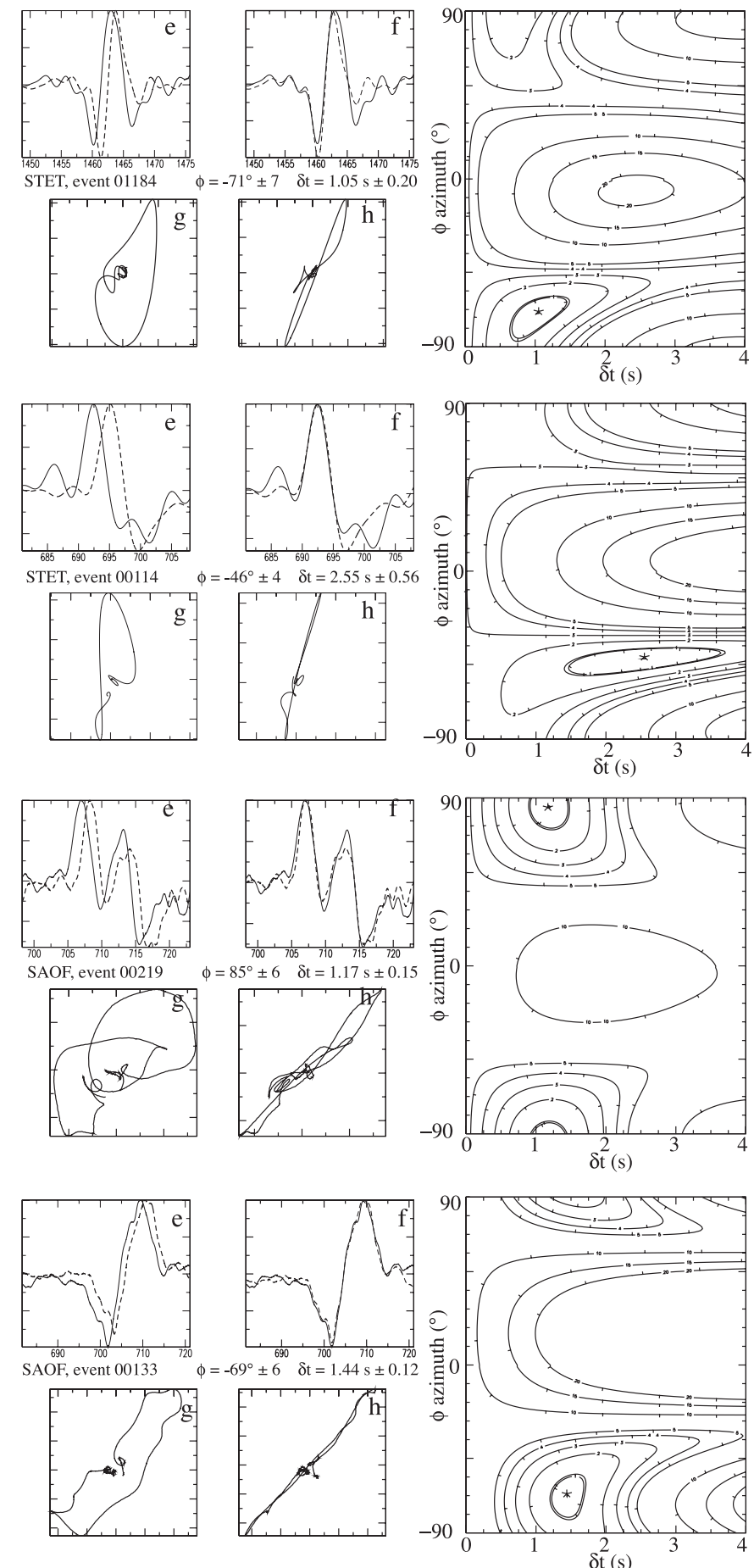

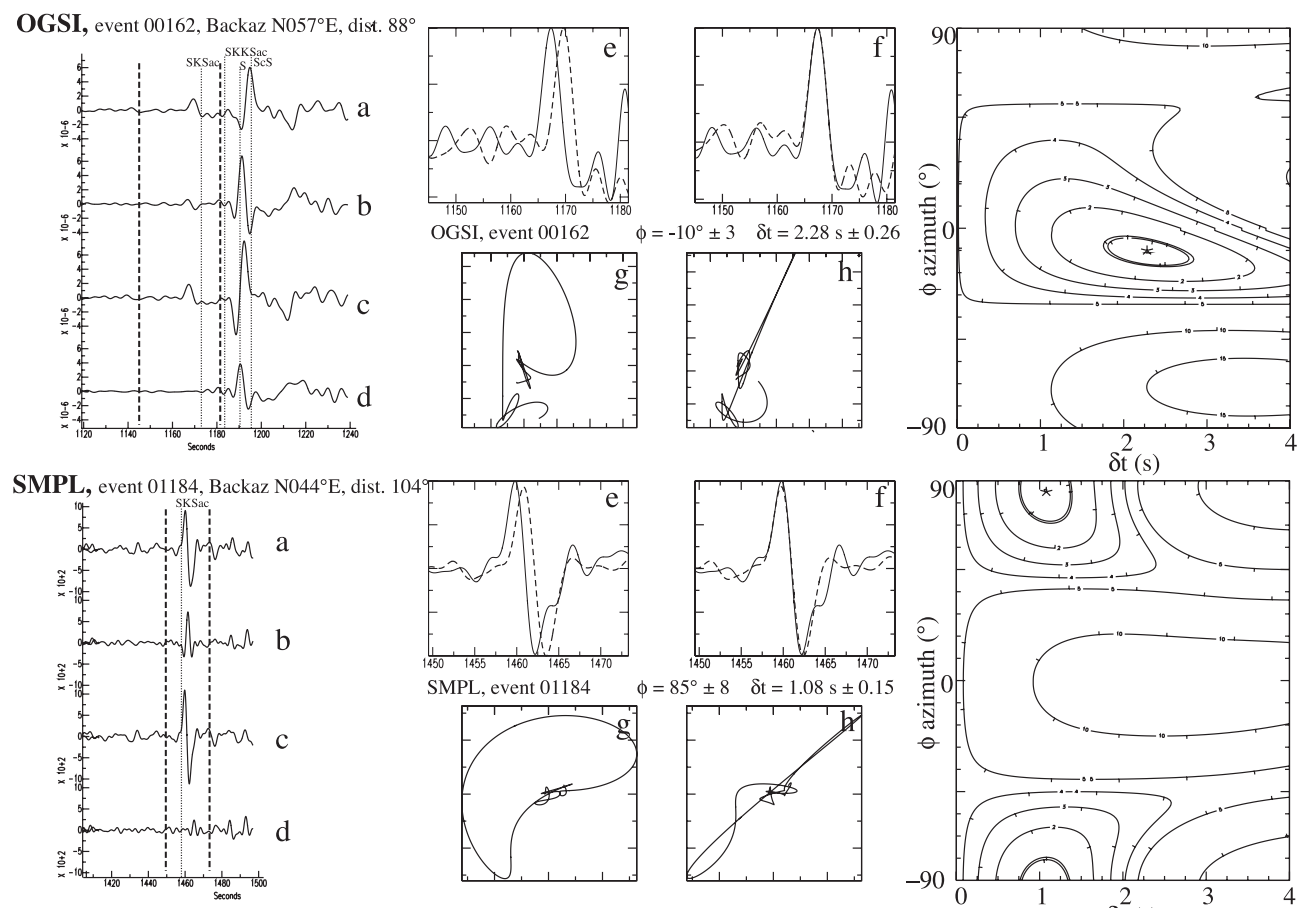

SMPL, event 01177, Backaz N251 ${ }^{\circ} \mathrm{E}$, dist. $95^{\circ}$
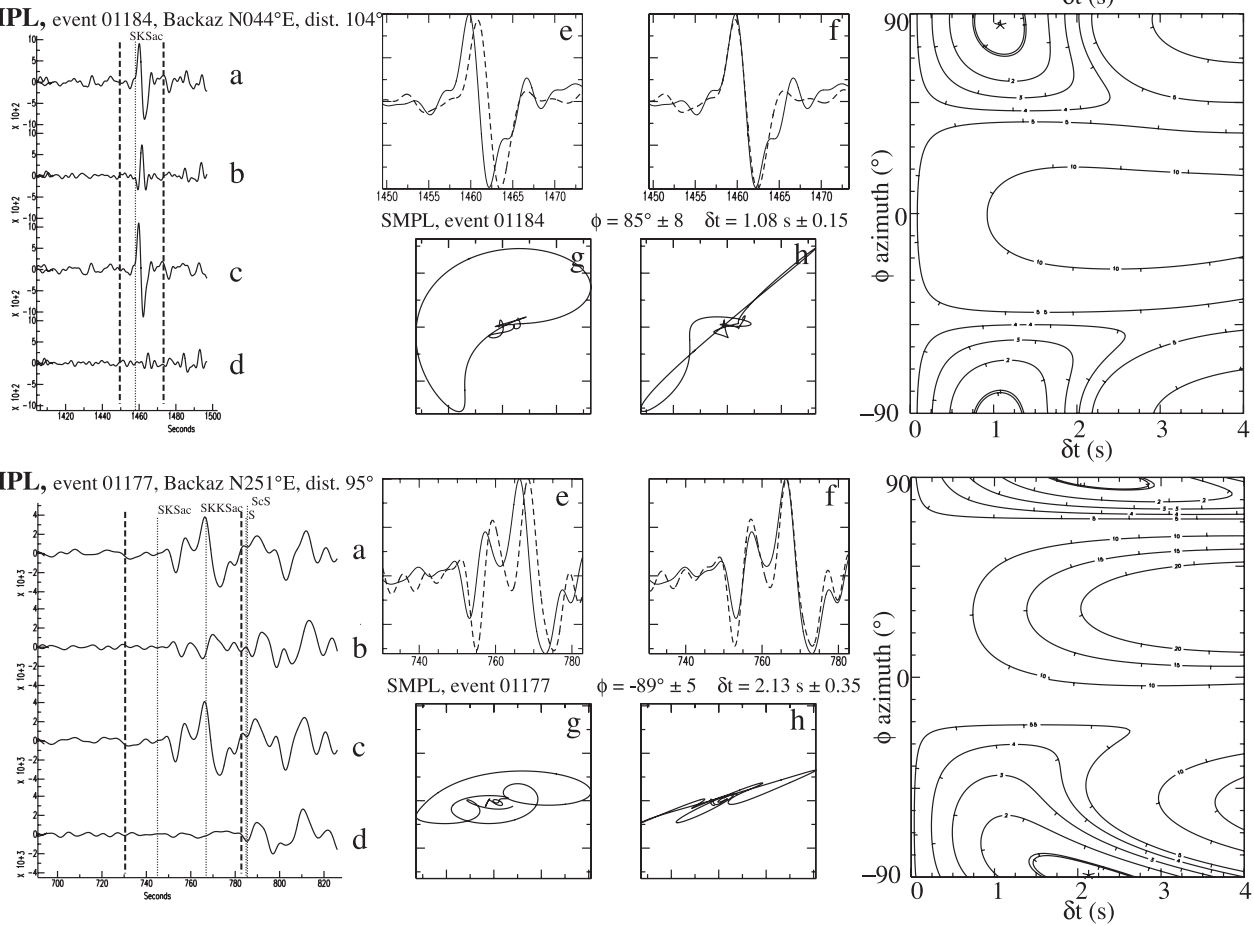

CALF, event 01177, Backaz N250 ${ }^{\circ} \mathrm{E}$, dist. $94^{\circ}$
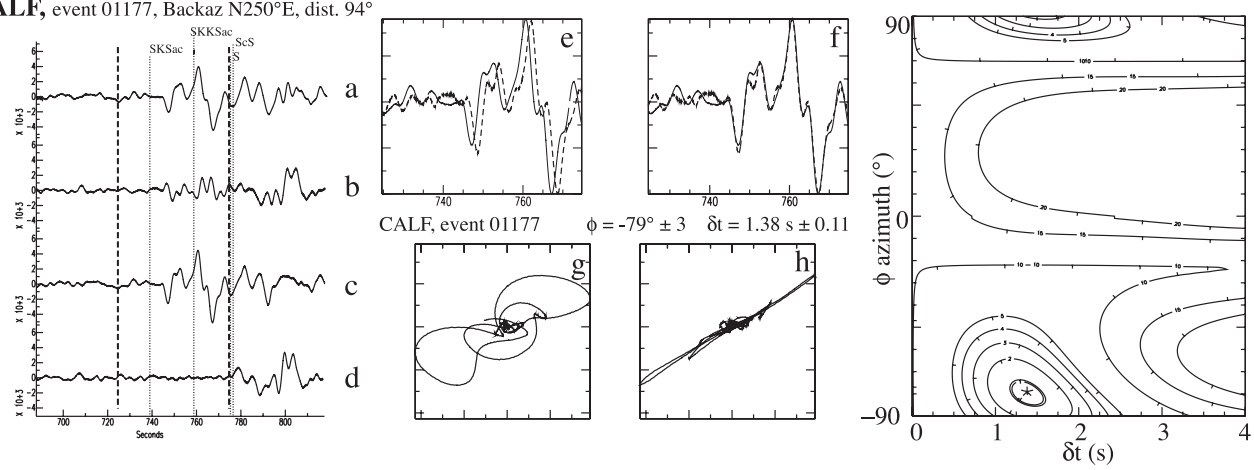

Fig. 2 (continued). 


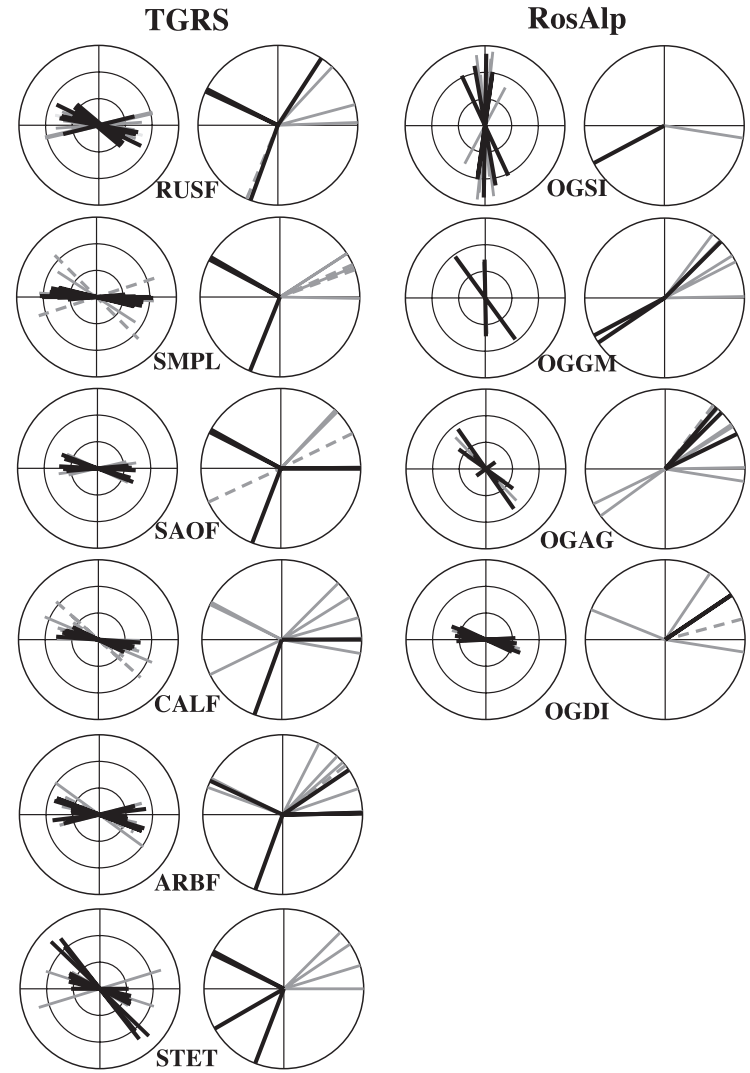

Fig. 3. For each station are presented the splitting (left) and the backazimuth for which no splitting are observed (right). For the splitting measurements, the trend of each segment represents the azimuth $\phi$ of the fast split shear wave and its length is proportional to the delay time $\delta t$ (up to $3.0 \mathrm{~s}$ ). Black lines correspond to well constrained results, dark gray lines to fair and dashed lines to poorly constrained results (Background Dataset, Table 3).

neous mantle structures beneath the stations. At the TGRS stations, numerous high-quality measurements have been observed at all stations. The azimuth $\phi$ of the fast split shear waves trend in a first approximation between $\mathrm{E}-\mathrm{W}$ and about $\mathrm{N} 100^{\circ} \mathrm{E}$, except at STET where some events led to a $\mathrm{N} 140^{\circ} \mathrm{E}$ fast split direction. The E-W trending anisotropy observed at the Corsica station SMPL is similar to the finding of Margheriti et al. (1996) at the temporary stations NAP0 and NAP1 installed in northern Corsica and in the Elba Island further East as well as at the Mednet permanent station VSL in Sardinia (Margheriti et al., 2003). At the RosAlp network, the southernmost station OGDI $(\phi$ trending $\mathrm{N} 100^{\circ} \mathrm{E}$ and $\delta t=1.12 \mathrm{~s}$ ) shows similar results than the surrounding TGRS stations. Results at the northern RosAlp sites are different since $\phi$ rotates gradually to the NW at OGAG, to the NNW at OGGM, and to the North at OGSI.

The diagrams in Fig. 3 show at few stations some variability in the anisotropy parameters that could result from either several layers of anisotropy, from inclined anisotropic structures or from lateral variations in the upper mantle structure. STET is the best example with two groups of parameters, one trending roughly $\mathrm{N} 100^{\circ} \mathrm{E}$ and with $\delta t$ slightly above $1.0 \mathrm{~s}$ and another trending $\mathrm{N} 140^{\circ} \mathrm{E}$ and with much larger $\delta t$, around $2.0 \mathrm{~s}$ (see examples in Fig. 2). In order to better understand the origin of such scattering, we present in Fig. 4 the projection of the individual splitting measurements at $100-\mathrm{km}$ depth along the incoming ray: this representation allows to visualize the lateral sampling of the anisotropy measurements and the regional-scale stability of the anisotropy parameters. It is helpful primarily by the fact that it plots the splitting parameters at a location where it could have been (at least partially) acquired. This is interesting for the cases where the crust and the lithosphere are known to have complex and dipping geometries such as in the Alpine collision and along the border of the Ligurian oceanic basins. Furthermore, in the hypothesis of an anisotropy pattern resulting from past or present asthenospheric flow, the observed pattern should be strongly influenced by the shape of the lithospheric root such as beneath the Alps, and one can therefore expect some lateral variations in the upper mantle anisotropy beneath some particular stations. Considering the ray paths through the structures is therefore of importance since they may not sample laterally the same structures depending on their backazimuths. Since the SKS measurements have little vertical resolution, we plot a final, integrated splitting at an arbitrary depth where splitting was perhaps not fully completed. A depth projection of $100 \mathrm{~km}$ is chosen. It is large enough to visually separate the various backazimuthal origins of the events and the regions of sampling of each ray. It likely plots measurements at sublithospheric depth in SE France and shows that the NE incoming events recorded at the station installed in the central Alpine units likely cross the Alpine lithospheric root at this depth.

The map shown in Fig. 4 first shows that the lateral mantle sampling is rather homogeneous at the scale of 


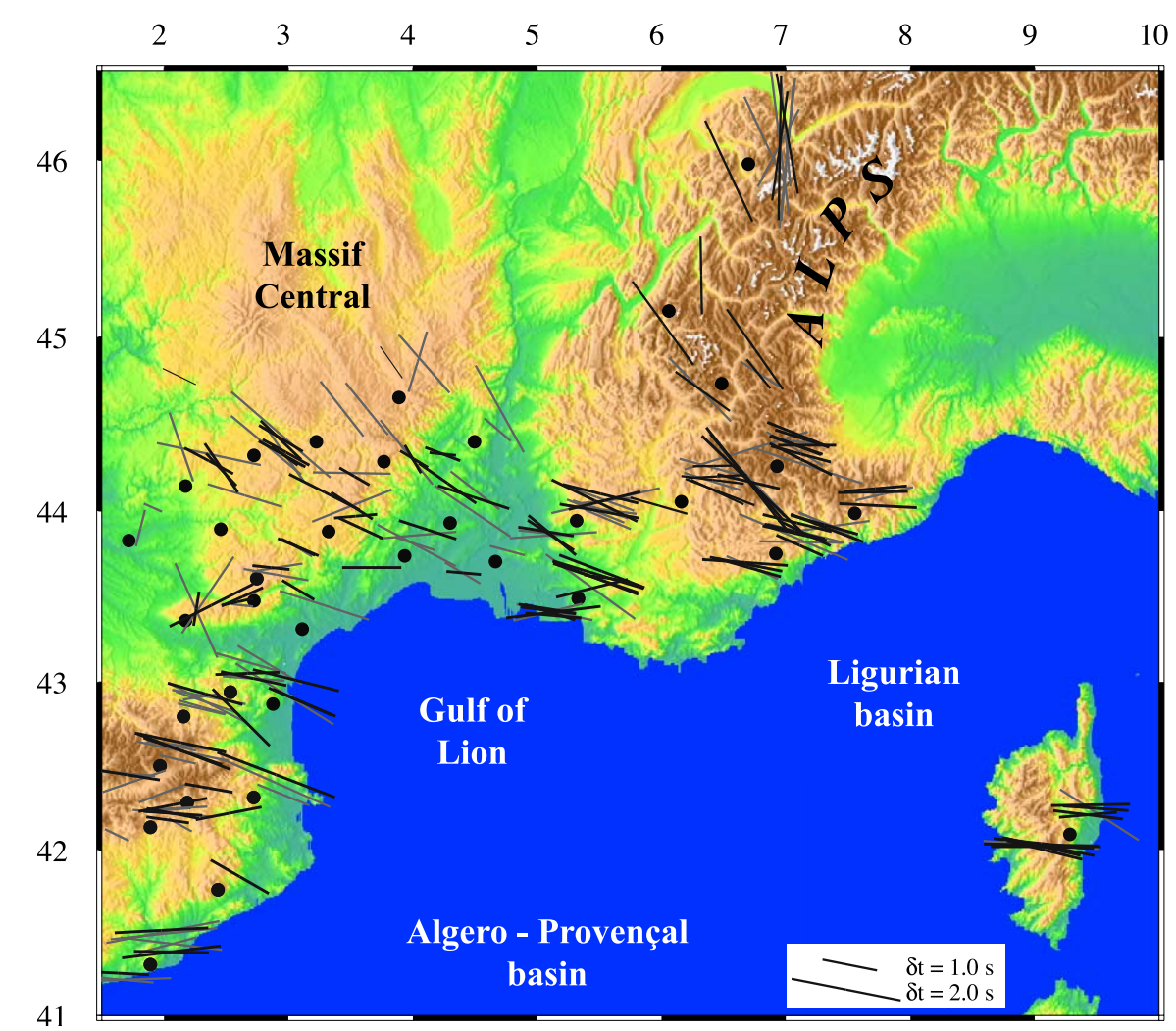

Fig. 4. Map of the SKS splitting measurements projected from the stations (black points) along the rays at 100-km depth. As for Fig. 3, the black measurements are the best constrained, and the gray measurements represent measurements of lower quality. Poor-quality measurements are not plotted on this figure. This map also displays projections of SKS splitting measurements from the Pyrenees (Barruol and Souriau, 1995; Barruol et al., 1998) and from the southern Massif Central (Barruol and Granet, 2002).

south-eastern France, but alternatively that the backazimuthal coverage at each station is rather sparse, most of the events arriving either from the NE or from the SW. Interestingly, projecting anisotropy results at depth shows that the apparent scattering observed in Fig. 3 is not a random feature that could be related to noisy measurements. Instead, the splitting results define coherent patterns consistent with either lateral variations in the upper mantle structure or with the presence of several anisotropic layers at depth, or with dipping structures. The best examples are visible at SAOF, STET, and SMPL. For these three stations, Fig. 2 illustrates some examples of split events arriving from the two opposite backazimuths. At SAOF, we do not find any strong variation in the delay times, but we observe a small dependence of $\phi$ on the event backazimuth; events arriving from the $\mathrm{NE}$ are characterized by $\phi$ trending almost E-W (three measurements of good quality give a mean of $\phi=\mathrm{N} 091^{\circ} \mathrm{E}$ ), whereas events arriving from the SW are characterized by $\phi$ trending $\mathrm{N} 109^{\circ} \mathrm{E}$ (from two goodquality measurements). The difference is rather small but based on high-quality measurements. SMPL in Corsica shows a backazimuthal dependence primarily on $\delta t$ and not on $\phi$, most of the high-quality $\phi$ trending E-W. Events arriving from the NE show smaller $\delta t$ than events arriving from the SW. The mean $\delta t$ obtained from the four high-quality events arriving from the NE is $1.27 \mathrm{~s}$, whereas the mean $\delta t$ obtained from seven high-quality measurements from the SW is $1.76 \mathrm{~s}$. At STET, both $\phi$ and $\delta t$ are clearly dependent on the backazimuth; events arriving from the NE are characterized by $\phi$ trending about $\mathrm{N} 110^{\circ} \mathrm{E}$ and by delay times ranging between 1.0 and $1.2 \mathrm{~s}$ (seven good measurements give mean values of $\phi=\mathrm{N} 107^{\circ} \mathrm{E}$ and $\delta t=1.12 \mathrm{~s}$ ), whereas events arriving 
from the SW are characterized by $\phi$ trending $\mathrm{N} 130^{\circ} \mathrm{E}$ and by much larger $\delta t$. From the four high-quality measurements obtained from SW backazimuths at STET, three display $\delta t$ above $2.0 \mathrm{~s}$ (the four highquality measurements give the mean values of $\phi=\mathrm{N} 130^{\circ} \mathrm{E}$ and $\delta t=2.06 \mathrm{~s}$ ).

Interestingly, the backazimuthal dependence is not an ubiquitous feature. Most of the stations displaying such characteristics are located within the Alpine belt, not only in its internal zone but also in the external domains. Although this feature can be explained by the presence of several layers of anisotropy (Silver and Savage, 1994), or from the presence of dipping structures in the mantle, it may simply result from lateral variations in the penetrative mantle deformation, i.e., from large-scale heterogeneities at upper mantle depth. Crustal and upper mantle dipping structures are already described in the western Alps by vertical seismic reflection (Bayer et al., 1989; Nicolas et al., 1990) or regional seismic tomography (Paul et al., 2001). Although such dipping structures can generate backazimuthal dependence of the anisotropy parameters if they are intrinsically anisotropic (Plomerova et al., 1998), resistive structures, such as the Alpine lithospheric roots, may laterally deflect the asthenospheric flow (Bormann et al., 1996) around it and therefore may introduce lateral variations in the upper mantle strain and anisotropy that may explain our observations; depending on the event backazimuth, the ray may indeed sample either the lithospheric root or the asthenospheric flow, resulting in backazimuthal dependence of the splitting parameters.

\section{Origin of the anisotropy}

The vertical location of anisotropy in the mantle is a key point to discuss SKS splitting measurements. Unfortunately, SKS splitting has a poor vertical resolution because the splitting of a teleseismic shear wave observed at the Earth's surface may be acquired anywhere along the ray between the station and the core-mantle boundary. It is, however, broadly accepted from seismological (Fischer and Wiens, 1995; Savage, 1999) and petrophysical arguments (e.g., Mainprice et al., 2000) that most of the anisotropy that affects the vertically propagating shear waves lies within the uppermost $400 \mathrm{~km}$ of the Earth. It is also broadly accepted from local earthquake or Mohoconverted S-phases analyses (Savage, 1999) and from laboratory measurements (Godfrey et al., 2000) or petrophysical modeling (Barruol and Mainprice, 1993) that the crust may contribute to the total observed delay times only to a few tenth of seconds, requiring most of the SKS splitting to be explained by subcrustal active or frozen mantle deformation.

Although the Hercynian deep and penetrative structures are poorly known in southeastern France since most of the area is covered by Mesozoic and Cenozoic sedimentary basins, there are some arguments favoring a sublithospheric origin of the anisotropy for the SE France stations. Hercynian terranes outcrop in Corsica, in the Maures Massif and in the basement of several Alpine massifs. Interestingly, the Maures massif is characterized by strong vertical, NS-trending, penetrative structures (Vauchez and Bufalo, 1988; Morillon et al., 2000) likely resulting from Hercynian strike-slip faulting. If some upper mantle deformation related to this structure was present at lithospheric depth, one should expect a NStrending anisotropy (Tommasi et al., 1999), which is not observed. There is no obvious correlation between the Hercynian structure and the observed anisotropy pattern, as observed for instance for the Sillon Houiller in the northern Massif Central (Babuska et al., 2002). The second argument that does not favor the Hercynian, lithospheric fabric as a primary source of our shear wave splitting observations is the homogeneity of the anisotropy pattern compared to the heterogeneity of the Hercynian structures (Matte, 1986), mainly formed by South-verging crustal nappes in the Massif Central. This discussion was already developed by Barruol and Granet (2002) for the southern Massif Central and is a fortiori valid for a larger zone where a homogeneous anisotropy pattern is observed. Third, the absence of clear correlation between the Pn fast anisotropic directions and the direction of the polarization of the fast split SKS waves in southeastern France and Corsica (Mele et al., 1998; Judenherc et al., 1999) suggests that the main source of the SKS splitting is deeper than the mantle sampled by Pn waves. Assuming Pn waves are affected by structures within the 10 uppermost $\mathrm{km}$ of the lithospheric mantle, the absence of correlation between Pn and SKS fast directions implies either a deeper source of SKS splitting within the lithosphere 
(requiring the presence of two layers of independent and penetrative strain within the lithosphere), or, as we propose, that a large part of the recorded shear wave splitting in SE France originates at sublithospheric depth. These arguments are primarily valid for the stations installed from the Massif Central to the external parts of the Alps. For the stations sitting in the internal zones of the belt, Alpine, penetrative lithospheric structures are likely to be present at depth, and therefore, the observed shear wave splitting at these stations may also reflect the upper mantle deformation related to the Alpine collision.

\section{Cenozoic asthenospheric flow and the Alpine lithospheric root}

The Neogene plate reconstruction in the western Mediterranean area is characterized by a complex geometry and history with simultaneous compression in the Alps (the westward collision of the Apulian plate with the Eurasian plate) and extension few hundreds of kilometers South in the Liguro-Provençal basin (e.g., Gueguen et al., 1998). Interestingly, the area covered by the TGRS network corresponds to the boundary between both regions. The upper mantle beneath this area has likely suffered strong differential motions able to develop strong and coherent anisotropy. We wish to show that this complex Cenozoic plate reorganization may have induced a regional asthenospheric flow that may be preserved since that time and that could explain the present-day observed anisotropy pattern.

From upper Cretaceous to the end of Eocene times, the general tectonic regime of the western Mediterranean is controlled by the northward motion of Africa inducing the continuous closure of the Tethys Ocean by its subduction beneath the Eurasian active margin. At Oligocene times, the collision of the Adriatic promontory with Eurasia generated important changes in the geodynamic evolution of the western Mediterranean. Between 30 to $22 \mathrm{Ma}$ (Fig. 5a), the southern France suffered the rifting of the continental lithosphere located between the Languedoc and the Corsica-Sardinia block (Séranne, 1999). The extension directions are oriented NW-SE in the southern Massif Central and rotate slightly to $\mathrm{E}-\mathrm{W}$ in SE France (Séranne, 1999). This regional Oligocene extension is interpreted as back-arc spreading induced by the early stages of the eastward roll-back of the Apenninic slab subducting toward the northwest beneath the Corsica-Sardinia lithospheric block.
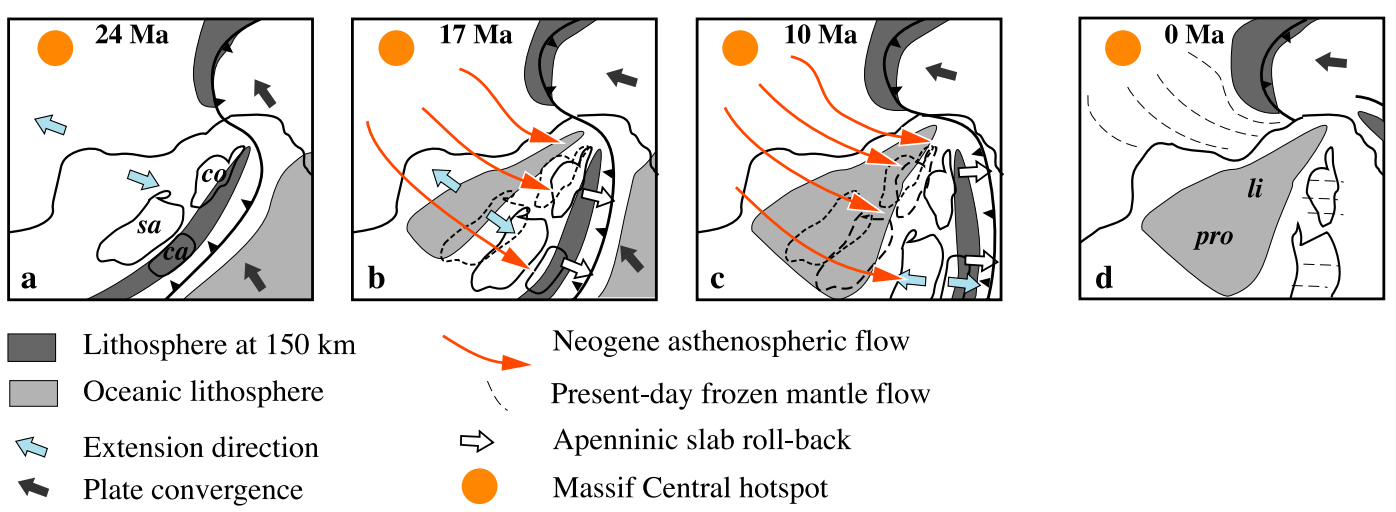

$$
\begin{aligned}
& \text { Neogene asthenospheric flow } \\
\Rightarrow \quad & \text { Present-day frozen mantle flow } \\
& \text { Apenninic slab roll-back } \\
& \text { Massif Central hotspot }
\end{aligned}
$$

Fig. 5. Schematic map of the northwestern part of the Mediterranean domain, illustrating the main features of the Neogene tectonic evolution and the proposed model of related asthenospheric flow. Are located the main subduction zones, the assumed oceanic lithosphere (in light gray), the Massif Central hotspot (circles), the extension and compression directions and the direction of the Apenninic slab retreat. The dark gray areas correspond to regions where stiff lithospheres were likely present at 150 - to 200-km depth and that could have either induced (like the Apenninic slab retreat) or deflected the asthenospheric flow (like the Alpine lithospheric roots). At the end of Oligocene (a), the southern France is under extension but the Corsica (co)-Sardinia (sa)-Calabrian (ca) lithospheric blocks are still in their original places. Their rotation induced by the retreat of the Apenninic slab began at about $22 \mathrm{Ma}$ and ended around $17 \mathrm{Ma}$ (b), inducing the opening of the Liguro-Provençal oceanic domain (li-pro) and a NW-SE flow at asthenospheric depth. From 17 to 10 Ma occurred the rifting of the Corsica-Sardinia block (c), followed by the drifting of the Calabrian block and the subsequent opening of the Tyrrhenian basin. We propose that the present-day pattern of seismic anisotropy schematized by the thin dashed lines (d) is the frozen upper mantle flow resulting from this tectonic evolution. 
Between 22 and 17 Ma (Fig. 5b), the counterclockwise rotation of this lithospheric block caused by the sinking of the Apenninic slab in the upper mantle induced a strong lithospheric thinning between southeastern France and Corsica and the subsequent creation of new oceanic crust and lithosphere in the Liguro-Provençal basin (Faccenna et al., 2001a; Rollet et al., 2002). During the same time, the Apulian promontory collides further North in the Alps and the Eurasian plate subducts eastward, as seen from the present-day images of the deep crustal structures in the Alps imaged, for instance, by the ECORS seismic reflection profiles (Nicolas et al., 1990), by compiling recent seismic data (Waldhauser et al., 1998), or by local earthquakes seismic tomography (Paul et al., 2001). At the lithospheric scale, regional seismic tomography (Piromallo and Morelli, 2003) and Pwave residuals (Babuska et al., 1990) define a deep root beneath the western Alps down to about $200 \mathrm{~km}$ beneath the internal parts of the belt and thinning toward the South. Gravimetric map of the Alps (Masson et al., 1999) also points out the eastward dipping of the Eurasian crust and lithosphere. The contemporaneous westward collision of the Apulian promontory in the North and the eastward motion of the slab in the South implies that the southeastern France has been located during the lower Miocene above a zone of strong vertical shearing in the upper mantle, induced by the roughly $\mathrm{E}-\mathrm{W}$ relative plate displacements. At 10 Ma (Fig. 5c), the CorsicaSardinia block is in its present-day orientation but begins to be subjected to a rifting episode that is followed few Ma later by the SE drift of the Calabrian block, the creation of the new Tyrrhenian oceanic lithosphere, and the eastward jump of the Apenninic subduction (Faccenna et al., 2001a).

In a previous paper dealing with the southern Massif Central upper mantle anisotropy, Barruol and Granet (2002) proposed that the sinking of the Apenninic slab East of the Corsica-Sardinia block and the related opening of the Liguro-Provençal oceanic basin may have induced a NW-SE pressure gradient within the asthenosphere that could have generated the observed mantle flow beneath the southern Massif Central. The authors pointed out two important facts from this model: first, the presence at that time of the ascending hot and low viscous mantle plume beneath the Northern Massif
Central (Granet et al., 1995a) could explain why pulling the mantle from the northwest could have been mechanically easier than pulling it from laterally or from below the sinking slab. Second, the maximum intensity in the Massif Central volcanism (Maury and Varet, 1980) that occurred about 10 Ma ago is roughly synchronous with the end of the Corsica rotation, i.e., with the end of the slab suction, allowing the mantle plume to freely continue its upward motion and to generate the peak in the volcanic activity. The new anisotropy measurements performed at 10 supplementary broadband seismic stations in SE France and in the western Alps are still compatible with these ideas and indicate the possible deflection of the asthenospheric flow by the deep Alpine lithospheric roots.

The continuity of the anisotropy pattern from the Massif Central to the southern Alps and Corsica and its good correlation with the Tertiary extension directions (Séranne, 1999) and to the relative plate motions described above are strong arguments to relate the upper mantle anisotropy to this Cenozoic extensive episode. Several factors may explain why this mantle flow and its related anisotropy have been preserved and are still clearly visible: first, there has been no subsequent tectonic nor thermal episode after this Neogene event. Therefore, the corresponding upper mantle fabric could have likely been preserved (Vauchez et al., 1999). Second, the slow absolute velocity of the Eurasian plate [less than $10 \mathrm{~mm} /$ year in Nice area, deduced from the HS3-nuvell plate velocity models (Gripp and Gordon, 2002)] may not be sufficient to generate a strong shearing in the upper mantle able to erase the preexisting fabric.

Our anisotropy measurements could be also discussed in light of a model of parabolic, asthenospheric flow related to the passive spreading of the ascending Massif Central plume material beneath the moving Eurasian lithosphere, as proposed for the Eifel plume by K. Walker (personal communication, 2003). We, however, believe that the conditions for a simple parabolic spreading of the plume material beneath the lithosphere are not fulfilled in the case of the Massif Central hotspot. First, because the lithosphere thickness shows much stronger variations in southern France (Babuska et al., 2002) than beneath Germany (lithosphere thinning beneath the Massif Central and toward the Mediterranean oceanic basins, lithospheric 
roots beneath the Alps), that would perturb any mantle spreading. Second, because the slab roll-back in the western Mediterranean, by forcing a deflection of the plume upwelling toward the SE, has likely controlled and channeled the regional upper mantle flow. Finally, we only observe a partial anisotropy pattern around the Massif Central: most of the measurements are located on the southern side of the hotspot.

The parallelism of the fast split directions with the bending of the Alpine structures, particularly for the southern stations located on the external parts of the belt, suggests that the asthenospheric flow arriving from the northwest could have been deflected by the bottom of the eastward-dipping Eurasian lithosphere (Fig. 5c). Interestingly, the southern termination of the Alpine lithospheric root in the Nice area corresponds to the E-W trending $\phi$ (Fig. 5d). We propose that the southern tip of the Alpine belt may have deflected and concentrated this asthenospheric flow and may have induced lateral variation in the anisotropy magnitude. This may explain at least two characteristics in our measurements: (i) delay times are, overall, stronger in SE France where mantle strain within the asthenosphere could have been more concentrated than further West, beneath the southern Massif Central, where the flow may have been more diffuse, and (ii) the backazimuthal dependence observed at STET and SAOF may be explained by the fact that the seismic rays arriving from NE primarily cross the east-dipping Alpine lithospheric slab, as suggested by the tomographic models (Piromallo and Faccenna, 2004), whereas the SWincoming rays primarily cross the asthenospheric flow of stronger intrinsic anisotropy, generating the largest $\delta t$. The observed delay time variations may therefore reveal different penetrative deformations within the Alpine root and within the asthenosphere beneath the external part of the belt. Considering the amplitudes of shear wave anisotropy determined from petrophysical analyses of upper mantle rocks (e.g., Ben Ismail and Mainprice, 1998; Ben Ismail et al., 2001), the large $\delta t$ of about $2.0 \mathrm{~s}$ measured from SW backazimuths can be explained by $4 \%$ of anisotropy on a $220-\mathrm{km}$-long path, which is consistent with a rather strong asthenospheric flow beneath this area. The $\delta t$ of about $1.0 \mathrm{~s}$ obtained from NE incoming events at STET and SAOF can be explained by $3 \%$ of anisotropy on a $150-\mathrm{km}$-long path. Interestingly, such backazimuthal variations of the delay times disappear further west such as at RUSF or CALF. This may be explained by the fact that both the NE and SW incoming rays do not cross the Eurasian slab plunging beneath the Alps and could be primarily affected by the sublithospheric anisotropy.

The interpretation of the backazimuthal dependence of the delay times observed at SMPL in Corsica cannot be related to similar origin since there is likely no more Alpine lithospheric root beneath Corsica. On the contrary, there are evidences that the eastern, Alpine, Corsican lithosphere is thinner $(40 \mathrm{~km})$ than the western, Hercynian, Corsican lithosphere $(70 \mathrm{~km})$ (Béthoux et al., 1999). The observed backazimuthal dependence could therefore suggest either an anisotropy primarily lying within the lithosphere or the presence of several anisotropic layers beneath the island. A similar observation was held at the Mednet station VSL further South in Sardinia, where E-W trending $\phi$ are observed, together with high $\delta t$ (Margheriti et al., 2003).

In the present state of knowledge, there is no argument to interpret the splitting observed at the two northernmost stations of the RosAlp network (OGSI and OGGM) in terms of sublithospheric mantle flow. Except that they form a continuous anisotropy pattern with the other Alpine stations, the anisotropy at these stations may likely reflect deep Alpine pervasive deformation rather than asthenospheric flow. Much more measurements across the belt would be needed to better constrain the interpretation of upper mantle penetrative structures beneath the Alps.

\section{Conclusions}

Mapping the upper mantle flow in southeastern France displays a smooth pattern, in clear continuity with the pattern previously obtained in the southern Massif Central. The absence of correlation between the Pn and SKS fast anisotropic directions, together with the absence of correlation between the trend of the fast split shear waves with the few outcropping Hercynian structures, do not favor Hercynian, lithospheric fabric as a primary source of anisotropy. Instead, the trend we observe in SE France is compatible with a horizontal asthenospheric flow 
induced by the sinking of the Apenninic slab that began about $20 \mathrm{Ma}$ ago, accompanied by the rotation of the Corsica-Sardinia lithospheric block and the opening of the Ligurian oceanic basin. These new anisotropy measurements seem therefore to confirm that the sinking of the Apenninic slab has had a dramatic effect on the upper mantle structures: if it is broadly accepted that it generated the counterclockwise rotation of the Corsica-Sardinia lithospheric block and the subsequent opening of the LiguroProvençal basin, we show that it may have also induced a regional mantle flow at asthenospheric depth that filled the gap left behind it. Part of the mantle upwelling related to the Massif Central hotspot could have been pulled toward the southeast by the retreating slab. We also propose that the Alpine lithospheric root may have deflected and concentrated the mantle flow around its southern tip. This could explain the good correlation between our SKS fast split directions and the trend of the Alpine belt in SE France as well as the increase in the observed delay times at the stations in the Nice area.

\section{Acknowledgments}

Many thanks to C. Maron who manages the TGRS network and the data availability. We are grateful to P. Silver for his splitting analysis program. This paper benefited from constructive comments of P. Matte and from fruitful reviews of L. Margheriti and V. Babuska.

\section{Appendix A. Supplementary Data}

Supplementary data associated with this article can be found, in the online version, at doi:10.1016/j.tecto. 2004.08.002.

\section{References}

Babuska, V., Plomerova, J., Granet, M., 1990. The deep lithosphere in the Alps: a model inferred from P residuals. Tectonophysics 176, 137-165.

Babuska, V., Plomerova, J., Vecsey, L., Granet, M., Achauer, U., 2002. Seismic anisotropy of the French Massif Central and predisposition of Cenozoic rifting and volcanism by Variscan suture hidden in the mantle lithosphere. Tectonics 21 . doi:10.1029/2001TC901035.
Barruol, G., Granet, M., 2002. A Tertiary asthenospheric flow beneath the southern French Massif Central related to the west Mediterranean extension evidenced by upper mantle seismic anisotropy. Earth Planet. Sci. Lett. 202, 31-47.

Barruol, G., Mainprice, D., 1993. A quantitative evaluation of the contribution of crustal rocks to the shear wave splitting of teleseismic SKS waves. Phys. Earth Planet. Inter. 78, 281-300.

Barruol, G., Souriau, A., 1995. Anisotropy beneath the Pyrenees range from teleseismic shear wave splitting. Geophys. Res. Lett. 22, 493-496.

Barruol, G., Souriau, A., Vauchez, A., Diaz, J., Gallart, J., Tubia, J., Cuevas, J., 1998. Lithospheric anisotropy beneath the Pyrenees from shear wave splitting. J. Geophys. Res. 103, 30039-30054.

Bayer, R., Carozzo, M.T., Lanza, R., Miletto, M., Rey, D., 1989. Gravity modelling along the ECORS-CROP vertical seismic reflection profile through the western Alps. Tectonophysics 162, 203-218.

Ben Ismail, W., Mainprice, D., 1998. An olivine fabric database: an overview of upper mantle fabrics and seismic anisotropy. Tectonophysics 296, 145-157.

Ben Ismail, W., Barruol, G., Mainprice, D., 2001. The Kaapvaal craton seismic anisotropy: petrophysical analyses of upper mantle kimberlite nodules. Geophys. Res. Lett. 28, 2497-2500.

Béthoux, N., Deschamps, A., Nolet, G., Bertrand, E., Contrucci, I., Sosson, M., Ferrandini, J., 1999. The deep structure of Corsica (Mediterranean Sea) as inferred from broad band seismological profile. Geophys. Res. Lett. 26, 2661-2664.

Bormann, P., Gruenthal, G., Kind, R., Montag, H., 1996. Upper mantle anisotropy underneath central Europe: effect of absolute plate motion and lithosphere-asthenosphere boundary topography? J. Geodyn. 22, 11-32.

Faccenna, C., Becker, T.W., Lucente, F.P., Jolivet, L., Rossetti, F., 2001a. History of subduction and Back-arc extension in the Central Mediterranean. Geophys. J. Int. 145, 809-820.

Faccenna, C., Funiciello, F., Giardini, D., Lucente, P., $2001 \mathrm{~b}$. Episodic back-arc extension during restricted mantle convection in the Central Mediterranean. Earth Planet. Sci. Lett. 187, $105-116$.

Fischer, K.M., Wiens, D.A., 1995. The depth distribution of mantle anisotropy beneath the Tonga subduction zone. Earth Planet. Sci. Lett. 142, 253-260.

Godfrey, N.J., Christensen, N.I., Okaya, D.A., 2000. Anisotropy of schists: contribution of crustal anisotropy to active source seismic experiments and shear wave splitting observations. J. Geophys. Res. 105, 27991-28007.

Granet, M., Stoll, G., Dorel, J., Achauer, U., Poupinet, G., Fuchs, K., 1995a. Massif Central (France): new constraints on the geodynamical evolution from teleseismic tomography. Geophys. J. Int. 121, 33-48.

Granet, M., Wilson, M., Achauer, U., 1995b. Imaging a mantle plume beneath the French Massif Central. Earth Planet. Sci. Lett. 136, 281-296.

Gripp, A.E., Gordon, R.B., 2002. Young tracks of hotspots and current plate velocities. Geophys. J. Int. 150, 321-361.

Gueguen, E., Doglioni, C., Fernandez, M., 1998. On the post-25 Ma geodynamic evolution of the western Mediterranean. Tectonophysics 298, 259-269. 
Judenherc, S., Granet, M., Boumbar, N., 1999. Two-dimensionnal anisotropic tomography of lithosphere beneath France using regional arrival times. J. Geophys. Res. 104, $13201-13215$.

Kennett, B.L.N., 1995. Seismic traveltime tables. In: Ahrens, T.J. (Ed.), Global Earth Physics. A Handbook of Physical Constants, AGU Ref. Shelf. AGU, Washington, DC, pp. 126-143.

Lippitsch, R., Kissling, E., Ansorge, J., 2003. Upper mantle structure beneath the Alpine orogen from high resolution teleseismic tomography. J. Geophys. Res. 108 (B8), 2376. doi:10.1029/2002JB002016.

Lucente, F.P., Chiarabba, C., Cimini, G.B., Giardini, D., 1999. Tomographic constraints of the geodynamics evolution of the Italian region. J. Geophys. Res. 104, 20307-20327.

Mainprice, D., Barruol, G., Ben Ismail, W., 2000. The seismic anisotropy of the Earth's mantle: from single crystal to polycrystal. In: Karato, S.I. (Ed.), Earth's Deep Interior: Mineral Physics and Tomography from the Atomic to the Global Scale, Geodyn. Ser. AGU, Washington, DC, pp. 237-264.

Margheriti, L., Nostro, C., Cocco, M., Amato, A., 1996. Seismic anisotropy beneath the northern Apennines (Italy) and its tectonic implications. Geophys. Res. Lett. 23, 2721-2724.

Margheriti, L., Lucente, F.P., Pondrelli, S., 2003. SKS splitting measurements in the Apenninic-Tyrrhenian domain (Italy) and their relation with lithospheric subduction and mantle convection. J. Geophys. Res. 108 (B4), 2218. doi:10.1029/ 2002JB001793.

Masson, F., Verdun, J., Bayer, R., Debeglia, N., 1999. Une nouvelle carte gravimétrique des Alpes occidentales et ses conséquences structurales et tectoniques. C. R. Acad. Sci., Paris $329,865-871$.

Matte, P., 1986. Tectonics and plate tectonics model for the Variscan belt of Europe. Tectonophysics 126, 329-374.

Maury, R.C., Varet, J., 1980. Le volcanisme tertiaire et quaternaire en France. In: Autran, A., Dercourt, J. (Eds.), Géologie de la France-Evolution géologique de la France. Mem. BRGM No. 107, pp. 139-159.

Mele, G., Rovelli, A., Seber, D., Hearn, T.M., Barazangi, M., 1998. Compressional velocity structure and anisotropy in the uppermost mantle beneath Italy and surrounding regions. J. Geophys. Res. 103, 12529-12543.

Morillon, A.C., Feraud, G., Sosson, M., Ruffet, G., Crevola, G., Lerouge, G., 2000. Diachronous cooling on both sides of a major strike slip fault in the Variscan Maures Massif (SE France), as deduced from a detailed Ar/Ar study. Tectonophysics $321,103-126$.

Nicolas, A., Christensen, N.I., 1987. Formation of anisotropy in upper mantle peridotites - a review. In: Fuchs, K., Froidevaux, C. (Eds.), Composition, Structure and Dynamics of the Lithosphere-Asthenosphere System, Geodyn. Ser.. AGU, Washington, DC, pp. $111-123$.
Nicolas, A., Polino, R., Hirn, A., Nicolich, R., 1990. ECORSCROP traverse and the deep structure of the western Alps: a synthesis. Mém. Soc. Géol. Fr. 156, 15-27.

Paul, A., Cattaneo, M., Thouvenot, F., Spallarossa, D., Béthoux, N., Fréchet, J., 2001. A three-dimensional crustal velocity model of the south-western Alps from local earthquake tomography. J. Geophys. Res. 106, 19367-19390.

Piromallo, C., Faccenna, C., 2004. How deep can we find the traces of Alpine subduction? Geophys. Res. Lett. 31, L06605. doi:10.1029/2003GL019288.

Piromallo, C., Morelli, C., 2003. P wave tomography of the mantle under the Alpine-Mediterranean area. J. Geophys. Res. 108 (B2), 2065. doi:10.1029/2002JB001757.

Plomerova, J., Babuska, V., Scarpa, R., 1998. Teleseismic P-residual study in the Italian region; inferences on large scale anisotropic structure of the subcrustal lithosphere. Ann. Geofis. 41, 33-48.

Rollet, N., Déverchère, J., Beslier, M.O., Guennoc, P., Réhault, J.P., Sosson, M., Truffert, C., 2002. Back arc extension, tectonic inheritance, and volcanism in the Ligurian Sea, Western Mediterranean. Tectonics 21 (3). doi:10.1029/2001TC900027.

Savage, M.K., 1999. Seismic anisotropy and mantle deformation: what have we learned from shear wave splitting? Rev. Geophys. 37, $65-106$.

Séranne, M., 1999. The Gulf of Lion continental margin (NW Mediterranean) revisited by IBS: an overview. In: Durand, B., Jolivet, L., Horvath, F., Séranne, M. (Eds.), The Mediterranean Basins: Tertiary Extension Within the Alpine Orogen. Geological Society, London, pp. 15-36.

Silver, P.G., 1996. Seismic anisotropy beneath the continents: probing the depths of geology. Annu. Rev. Earth Planet. Sci. 24, $385-432$.

Silver, P.G., Chan, W.W., 1991. Shear wave splitting and subcontinental mantle deformation. J. Geophys. Res. 96, $16429-16454$.

Silver, P.G., Savage, M.K., 1994. The interpretation of shear-wave splitting parameters in the presence of two anisotropic layers. Geophys. J. Int. 119, 949-963.

Tommasi, A., Tikoff, B., Vauchez, A., 1999. Upper mantle tectonics: three-dimensional deformation, olivine crystallographic fabrics and seismic properties. Earth Planet. Sci. Lett. $168,173-186$.

Vauchez, A., Bufalo, M., 1988. Charriage crustal, anatexie et décrochement ductile dans les Maures orientales (Var, France) au cours de l'orogène Varisque. Geol. Rundsch. 77, 45-62.

Vauchez, A., Barruol, G., Nicolas, A., 1999. Comment on "SKS splitting beneath rift zones". J. Geophys. Res. 104, 10787-10789.

Waldhauser, F., Kissling, E., Ansorge, J., Mueller, S., 1998. Three dimensionnal interface modelling with two-dimensional seismic data: the Alpine crust-mantle boundary. Geophys. J. Int. 135, 264-278. 